\title{
On the role of heterotrophic bacteria in marine ecosystems: Some problems
}

\author{
C. JOIRIS \\ Laboratorium voor Ekologie en Systematiek, Vrije Universiteit Brussel; \\ Brussel, Belgium
}

\begin{abstract}
Resulting from synecological studies in some areas of the southern North Sea, a contradiction becomes evident between measurements of primary production and determinations of the activities consuming organic matter. In the Southern Bight, the consumption in 10 times higher than the production. This means that the primary production has been underestimated, and/or the consumption over-estimated. In order to discuss the validity of the methods used for determining the respiration activities, some results are presented: (a) during a $24-\mathrm{h}$ cycle at the Sluice-Dock of Ostend, the variations of the oxygen concentration in the water are explained by the measured activities and diffusion fluxes; (b) two different methods are shown to give comparable results: the initial rate of oxygen consumption and the anaplerotic fixation of $\mathrm{CO}_{2}$. The other possible sources of error lie mainly in the extrapolations one has to make in order to establish a general budget: (a) extrapolation in time is very difficult because of important variations of organic matter and respiration activities to be observed during a 24-h cycle; (b) extrapolation in function of the depth does not seem very difficult in the case of shallow, entirely mixed water masses. No argument was found against the validity of the methods used for the determination of respiration activities. Therefore, the question remains open as to which parameters are over-estimated or under-estimated by actual methods.
\end{abstract}

\section{INTRODUCTION}

For a few years now, we have attempted to describe and understand the ecometabolism of some biocoenoses in the southern North Sea. In this synecological approach, it was necessary to determine simultaneously the main characteristics of the carbon and nitrogen cycles: biomasses and concentrations, fluxes and activities.

This was done in a shallow artificial lagoon, linked by sluices with the harbour of Ostend, Belgium (Fig. 1). Once the basin has been filled in March, the sluices normally remain closed until September, giving the opportunity to follow changes in this water mass for about 6 months. The surface of the Sluice-Dock is about 86 ha; its mean depth, $1.5 \mathrm{~m}$. Samples were generally taken once a week; in some periods, every day; and every $2 \mathrm{~h}$ for a few days. All experimental determinations started in the laboratory within $1 \mathrm{~h}$ of sampling. Similar work was also done in the Southern Bight of the North Sea (Fig. 2). 
The methods used here were already described and discussed (Jo Podamo, 1973, 1975), including the reproductibility of our sampling and counting techniques (Jo Podamo, 1972).

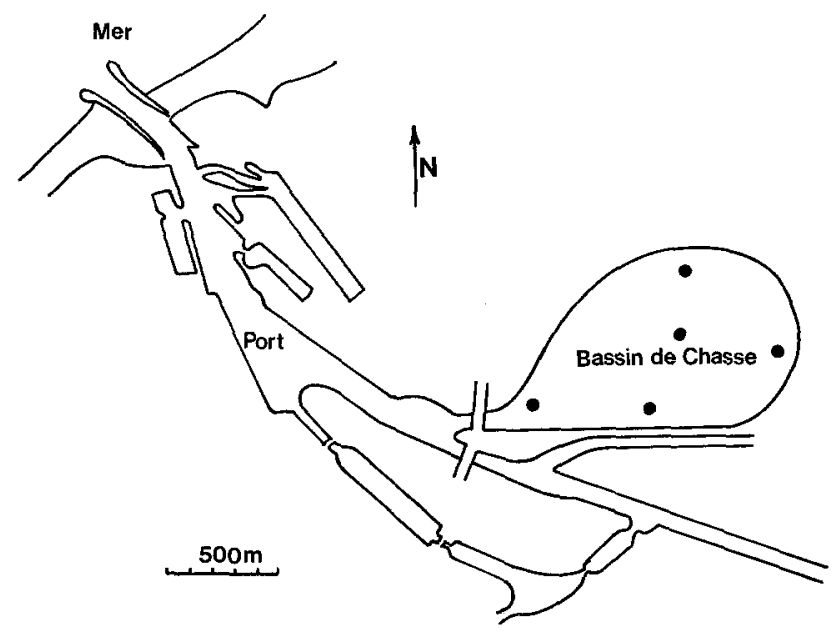

Fig. 1 : Position of Sluice Dock at Ostend (Bassin de Chasse) and its connections with harbour (port) and open sea (mer)

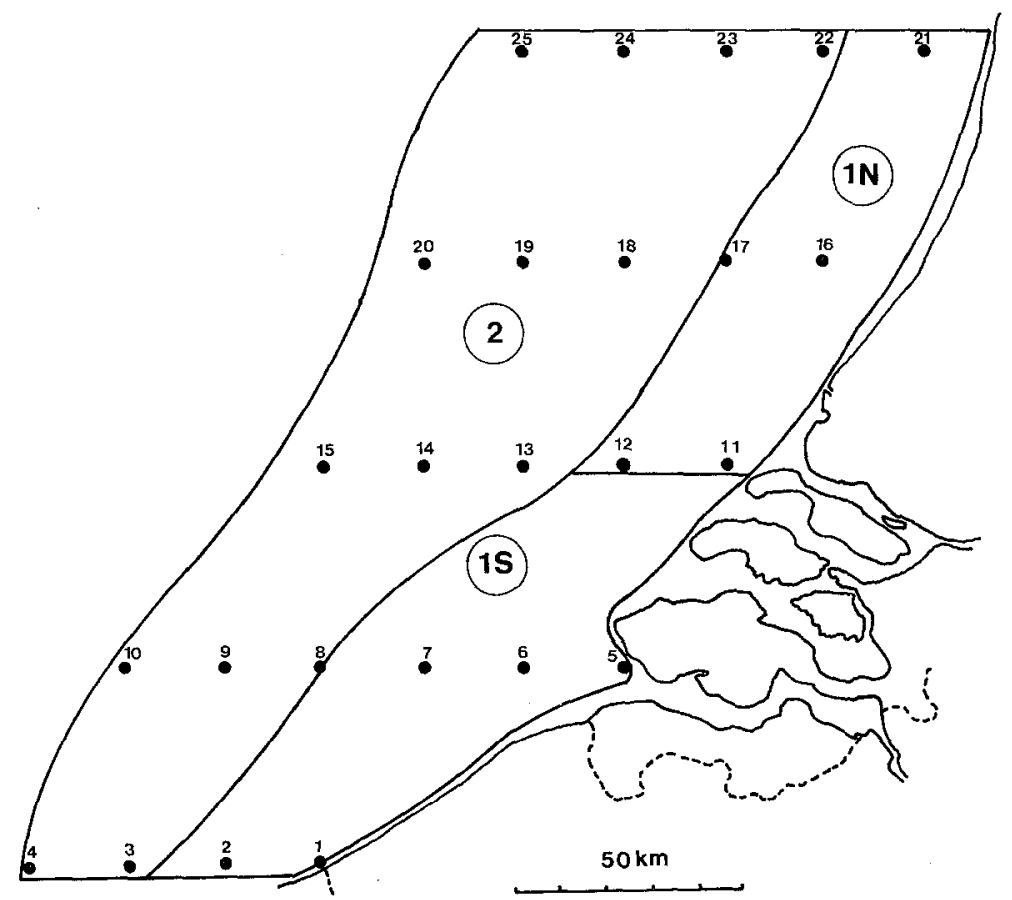

Fig. 2: The three zones (1 S, $1 \mathrm{~N}, 2)$ in the Southern Bight, North Sea 


\section{RESULTS AND DISCUSSION}

As an example, some results obtained for the carbon cycle are discussed for the Sluice-Dock (Fig. 3) and for two zones of the Southern Bight (Figs. 4 \& 5). A summary of these results is presented in Table 1; more details have been published under the team name Jo Podamo $(1973,1975)$. The results obtained in the Sluice-Dodk (Table I, Column 1) show that the budget is unbalanced, and that there is a contradiction between the amount of organic matter formed by primary production and the amount used by the consumers. Consumption is almost twice as high as production.

T'able 1

Mean values for the production and consumption activities in different biocoenoses of the Southern North Sea

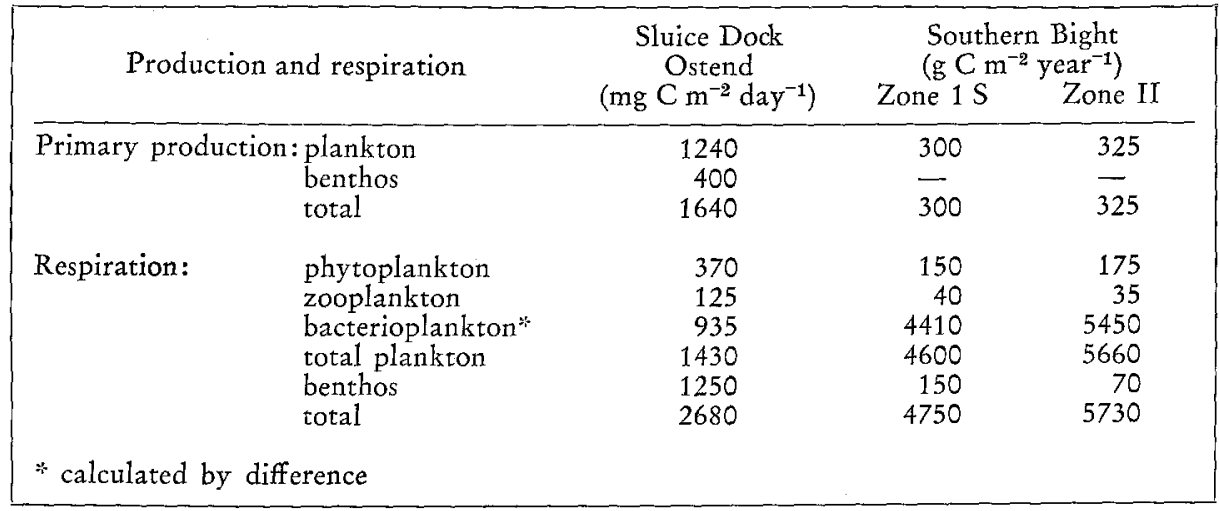

But from similar results obtained in the Southern Bight of the North Sea (Table 1, Columns 2 and 3), consumption is 10 times higher than production. This discrepancy cannot be explained by sources of external organic matter, since this influence is practically limited to the estuary of the Scheldt (Wollast, 1976).

Moreover, the budget of oxygen concentration in the water reveals in both zones of the North Sea, particularly in Zone $1 \mathrm{~S}$, a surplus production of oxygen. Clearly, the differences in activities must be in favour of primary production (Fig. 6; Jo Podamo, 1975). Obviously, some measured parameters do not reflect reality. Either primary production must have been under-estimated, or the consuming activities overestimated.

A critical discussion is urgently required regarding the validity of the methods we are utilizing. In our particular case; we must discuss the methods used for determining planktonic respiration.

The first method consists of following the consumption of oxygen in fresh water samples in the dark and at natural temperatures (Fig. 7). From the kinetics of disappearance of oxygen, we took the initial rate of consumption as reflecting the real respiration rate. From the same experiment we obtained values for the content of biodegradable organic matter, after 5-day incubation $\left(\mathrm{BOD}_{5}\right)$. 


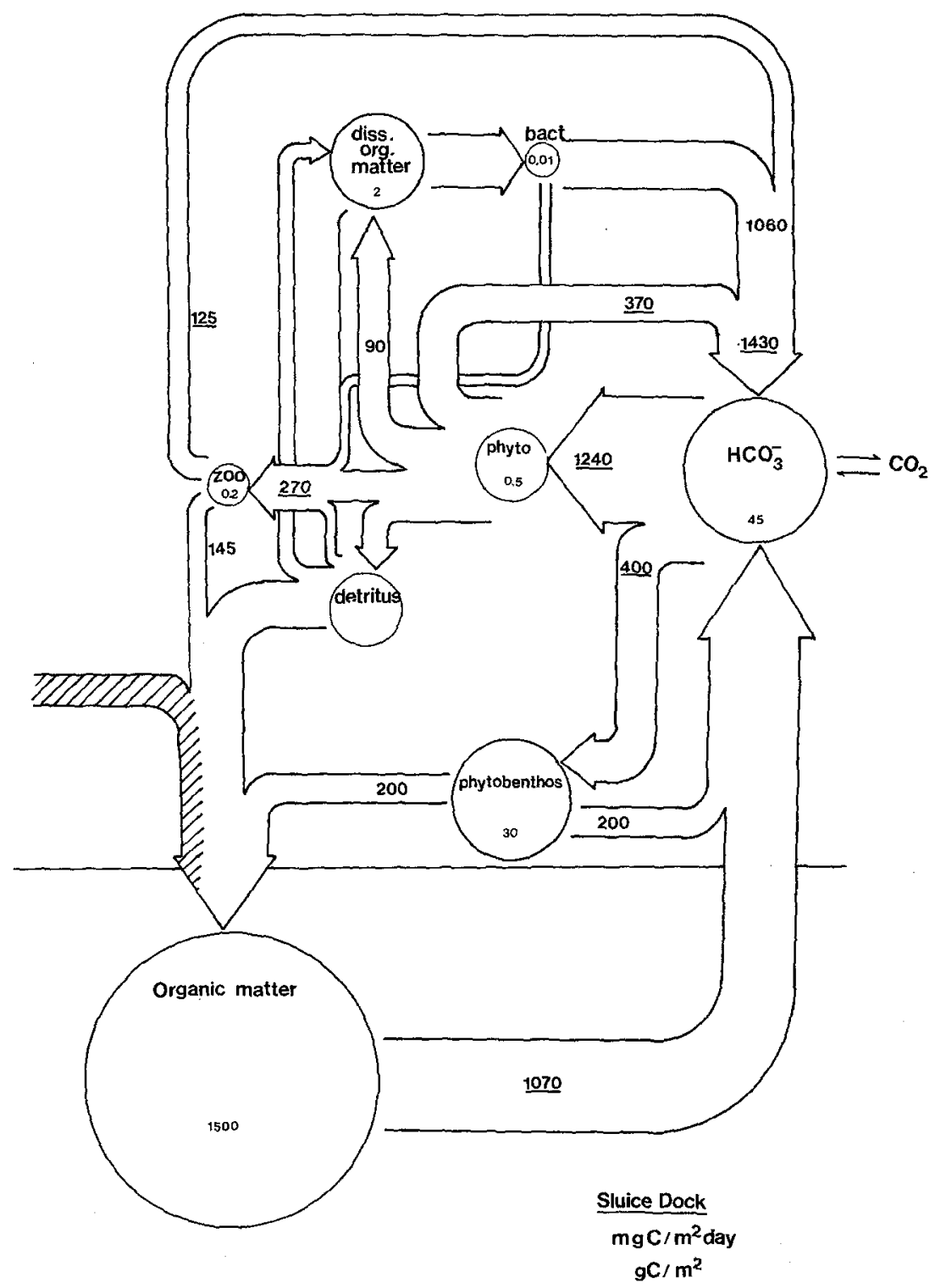

Fig. 3: Schematic representation of main concentrations and fluxes of the carbon cycle in the Sluice Dock of Ostend; March-September 


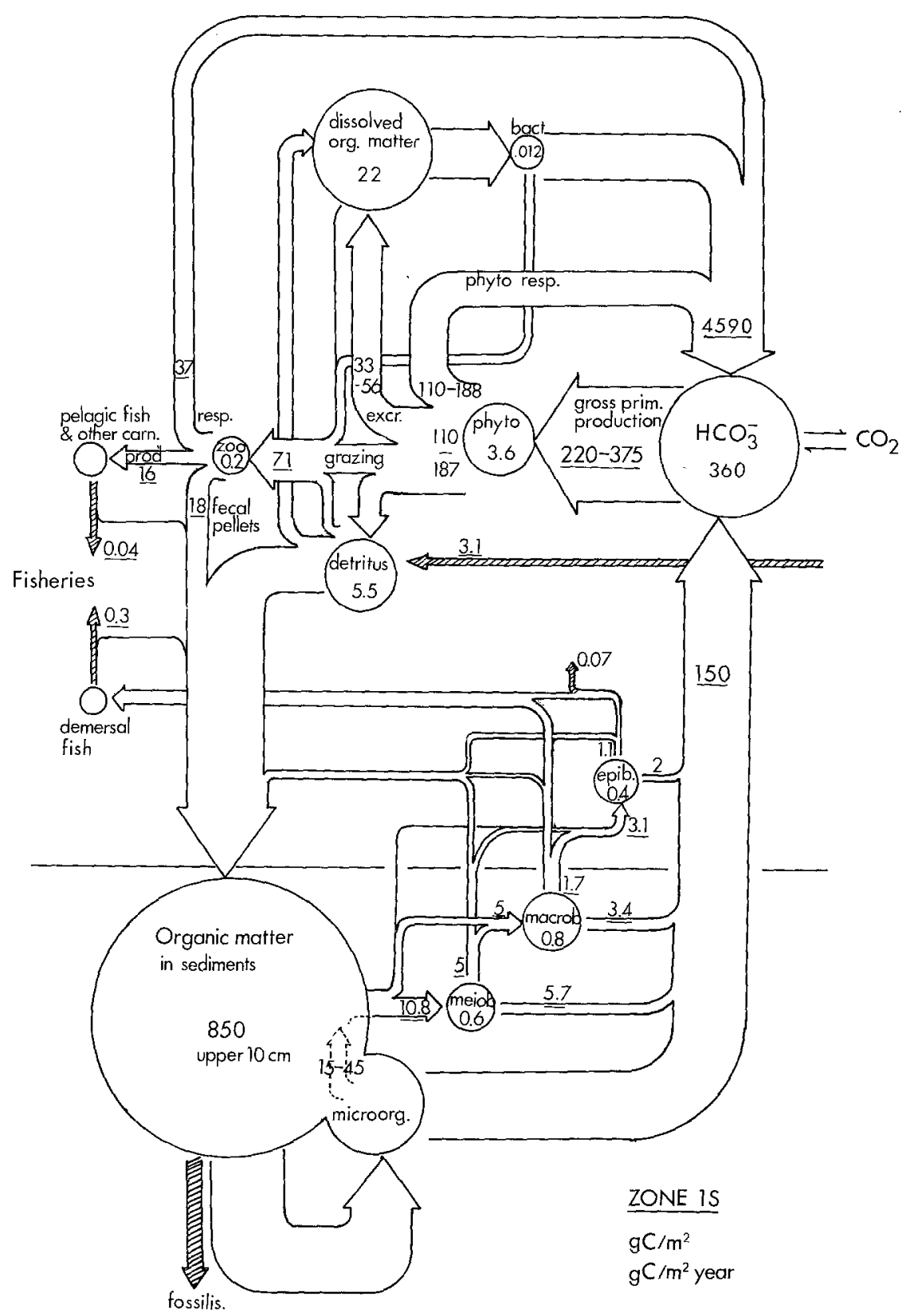

Fig. 4: Carbon cycle in Zone $1 \mathrm{~S}$ of Southern Bight 


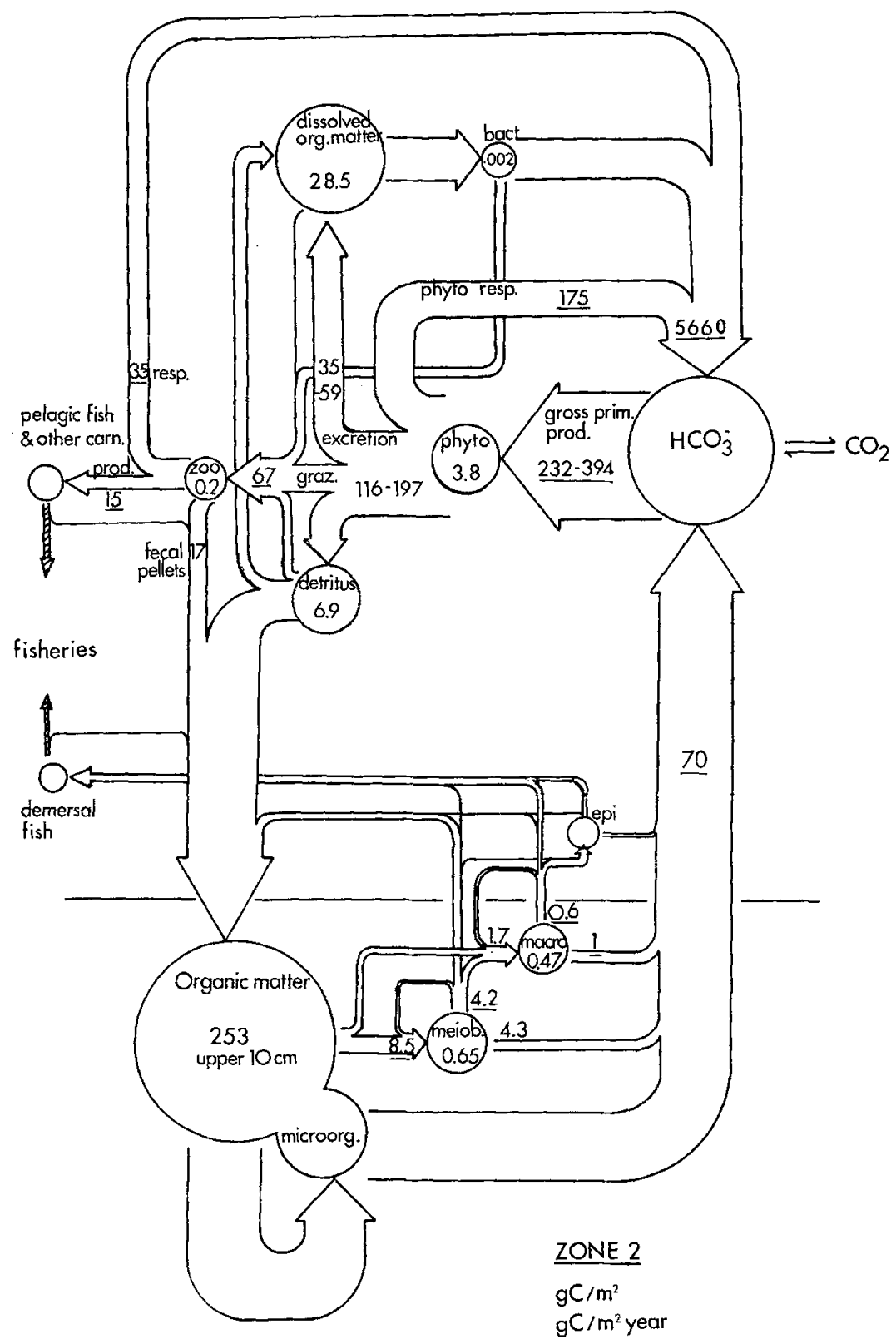

Fig. 5: Carbon cycle in Zone 2 of Southern Bight 


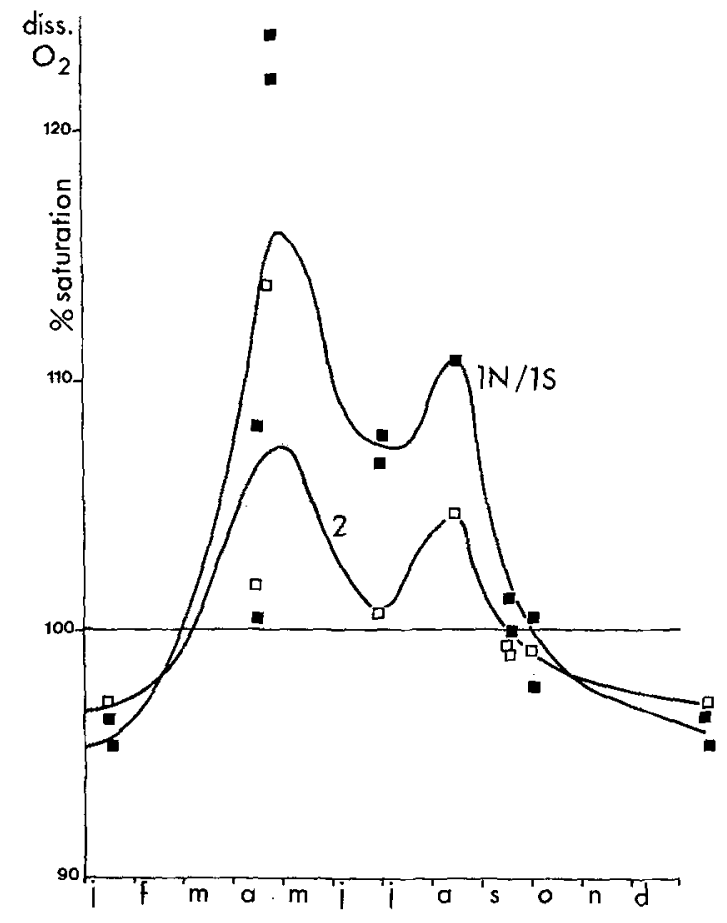

Fig. 6: Oxygen concentration in the water of different zones of the Southern Bight

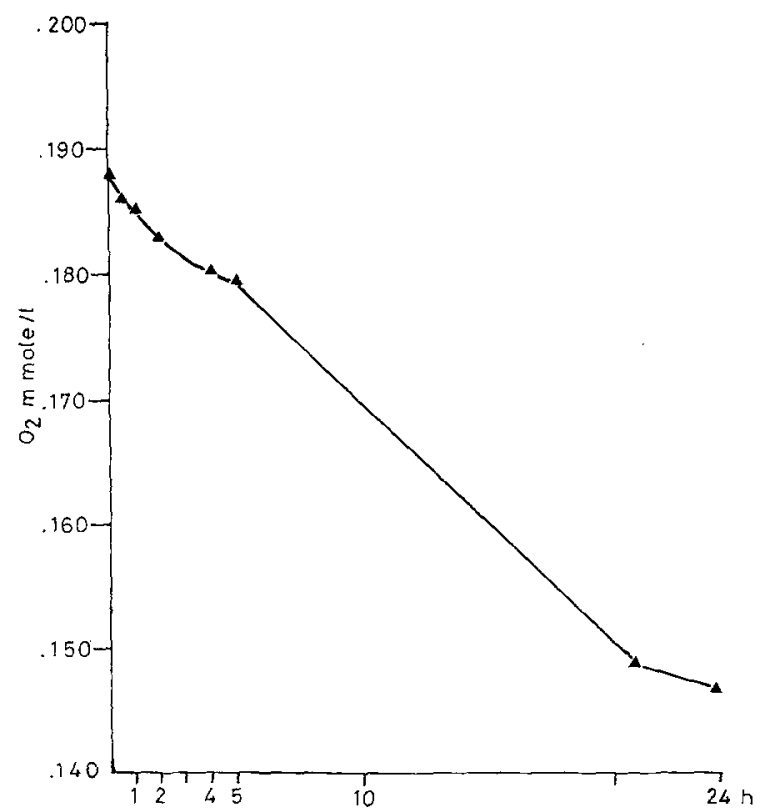

Fig. 7: Consumption rate of oxygen in the dark: an example. Sluice Dock of Ostend (05.08. 1974) 


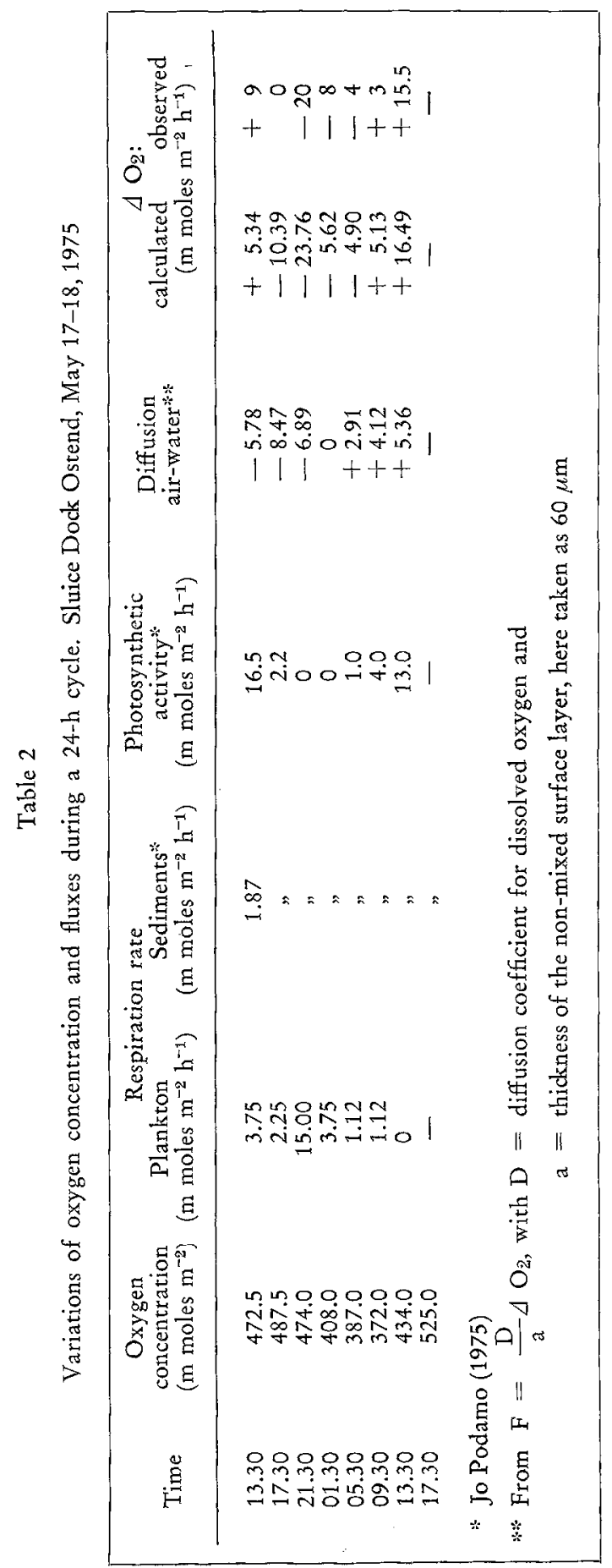


In order to test the validity of the method, one can use the different values obtained during a 24-h cycle in the Sluice-Dock (Table 2). It will be noticed that the nightly decrease in oxygen concentration is entirely explained by 3 factors, namely (a) measured planktonic respiration, (b) measured benthic respiration, and (c) calculated diffusion exchanges between water and air.

These results seem to indicate that the method is valid. This was further checked by comparing the results obtained with another method: the anaplerotic dark fixation of radioactive $\mathrm{CO}_{2}$, as proposed by Romanenko (1964). We found a good relation between these two methods, with a conversion factor of 30 (Table 3 ).

Once the individual determinations are found valid, the next sources of error to be considered concern the extrapolations made in order to establish mean values for the respiratory activities.

Table 3

Comparison between respiration, as measured by oxygen consumption, and anaplerotic fixation of radio-active $\mathrm{CO}_{2}$. (Ostend, March 29, 1974. $\mathrm{RQ}=0.85$ )

\begin{tabular}{|c|c|c|c|c|}
\hline No. & $\mathrm{O}_{2}\left(\mathrm{~m}_{\text {moles }} \mathrm{m}^{-3} \mathrm{~h}^{-1}\right)$ & $\begin{array}{l}\mathrm{C}\left(\mathrm{m} \text { moles } \mathrm{m}^{-3} \mathrm{~h}^{-1}\right) \\
\text { iration }\end{array}$ & $\begin{array}{c}\text { Dark fixation } \\
\mathrm{CO}_{2}\left(\mathrm{~m} \text { moles } \mathrm{m}^{-3} \mathrm{~h}^{-1}\right)\end{array}$ & $\begin{array}{c}\text { Conversion } \\
\text { factor }\end{array}$ \\
\hline 1 & 20 & 17 & 0.57 & 29.8 \\
\hline 2 & 10 & 8.5 & 0.28 & 30.3 \\
\hline 3 & 4 & 3.4 & 0.10 & 34 \\
\hline 4 & 8 & 6.8 & $(>0.32)$ & $(>21.2)$ \\
\hline 5 & 2.7 & 2.3 & $0.10^{\prime}$ & 22.9 \\
\hline \multirow[t]{2}{*}{6} & 1 & 0.85 & 0.05 & $(<42.5)$ \\
\hline & & & & $\mathrm{m}=29.25$ \\
\hline
\end{tabular}

Table 4

Measurements of planctonic respiration as a function of depth. Vi.: initial oxygen consumption rate $\left(\mathrm{m}\right.$ mole $\left.\mathrm{O}_{2} \mathrm{~m}^{-3} \mathrm{~h}^{-1}\right)$

\begin{tabular}{|cccc|}
\hline Date & $\begin{array}{c}\text { Station } \\
\text { number }\end{array}$ & $\begin{array}{c}\text { Depth } \\
(\mathrm{m})\end{array}$ & Vi \\
\hline 06.01 .1975 & 20 & 0 & 1.0 \\
& & 16 & 0.9 \\
& 01 & 33 & 0.3 \\
03.02 .1975 & 0 & 0.2 \\
& & 4.5 & 0.8 \\
& & 9 & 2.1 \\
28.04 .1975 & 18 & 0 & 1.8 \\
& & 13 & 0.3 \\
& 22 & 26 & 0.1 \\
28.04 .1975 & 22 & 0 & 3.0 \\
& & 10 & 1.0 \\
& & 20 & 0.9 \\
16.06 .1975 & 22 & 0 & 0.8 \\
& & 20 & 1.2 \\
& & 0.8 \\
\hline
\end{tabular}


Very often, the values obtained in surface water are extrapolated to the whole water column. In our case, however, we are working within a completely mixed water column, and we did not find any important variations as a function of depth (Table 4). Another possible source of error, the effect of pressure, seems to be of very little importance, since one can expect an inhibitory effect of $50 \%$ only at a depth of $100 \mathrm{~m}$, but we are working at maximum depths of ca. $35 \mathrm{~m}$ for Zone II in the North Sea.

More important are the pronounced diel variations found for organic matter concentration and for planktonic respiration ('Table 5). Such important variations render dangerous any extrapolation from one or a few values to whole-day conditions.

Table 5

Variation in total planktonc respiration (Vi) and organic matter concentration $\left(\mathrm{BOD}_{5}\right)$ during a 48-h cycle, May 15-17, 1974

\begin{tabular}{|ccc|}
\hline Time & $\begin{array}{c}\mathrm{Vi} \\
\left(\mathrm{m} \text { moles } \mathrm{O}_{2} \mathrm{~m}^{-3}\right)\end{array}$ & $\begin{array}{c}\mathrm{BOD}_{5} \\
\left(\mathrm{~m} \mathrm{moles}_{2} \mathrm{~m}^{-3}\right)\end{array}$ \\
\hline 06.00 & 2.80 & $>180$ \\
08.00 & 0.76 & $>169$ \\
10.00 & 1.98 & $>180$ \\
12.00 & 2.04 & $>216$ \\
14.00 & 3.02 & $>223$ \\
16.00 & 0.56 & 102 \\
18.00 & 2.20 & 106 \\
20.00 & 2.60 & 104 \\
22.00 & 2.56 & $>226$ \\
24.00 & 2.56 & $>230$ \\
04.00 & 2.27 & 160 \\
08.00 & & 135 \\
10.00 & 3.79 & 162 \\
12.00 & 3.44 & $>237$ \\
16.00 & 4.08 & 115 \\
20.00 & 2.60 & \\
24.00 & 1.52 & \\
04.00 & & \\
\hline
\end{tabular}

\section{CONCLUSIONS}

(1) It is important to note that the consumers' activities determined fit, and are consistent with, values previously cited in literature. For instance, it seems clear that microbial respiration must be at least 10 times higher than that of zooplankton. It can also be considered normal that the main fraction of the total planktonic respiration is due to the "ultra-plankton" (Pomeroy \& Johannes, 1968). In our case, this was probably due to the bacteria, since only very small quantities of microzooplancton were observed under the microscope. Another example: a turnover rate of a few days for the organic matter can be considered normal in coastal waters (Jo Podamo, 1975; Seki et al., 1975). Finally, the values obtained for bacterial activities and organic matter also correspond closely with other determinations made in coastal waters in different parts of the world by applying various methods (see Jo Podamo, 1975).

(2) The same discrepancy between production and consumption rates has been found in oceanographic studies, as pointed out, for instance, by Banse (1974) who 
discussed results obtained by Sorokin (1973); Sieburth (1977) came to the same conclusion.

(3) The results presented and discussed here, together with results from the literature, indicate that the discrepancy between production and consumption in the sea has not yet been solved. We did not find evidence indicating that the respiration activity has been over-estimated, and we still have to assume that the primary production could have been under-estimated.

(4) A more general conclusion is to emphasize, once more, how important it is for ecological studies to measure fluxes and dynamics, rather than standing crop and concentration data. This is particularly necessary for the heterotrophic activities. We must use the synecological approach more systematically and try to measure completely the main fluxes of matter in an ecosystem, and thus endeavour to solve the problem of production activity versus consumption activities.

This can deeply modify our view of the relationships between phytoplankton, zooplankton grazing and the microbial recycling, at least in coastal waters. It must be noted, for instance, that the bacterial activity determined with an efficiency of $50 \%$, or only $30 \%$ as is generally accepted, would lead to an important production of bacterial biomass disposable for an potential zooplankton grazing.

\section{LITERATURE CITED}

Banse, K., 1974. On the role of bacterioplankton in the tropical ocean. Mar. Biol. 23, 1-5. Podamo, Jo., 1972. Evolution des populations de bactéries marines hétérotrophes au Bassin de Chasse d'Ostende (Belgique) en 1971. Biol. Jb. Dodonea 40, 291-303.

- 1973. Aspect of dynamic biology in the Southern Bight of the North Sea and the SluiceDock at Ostend. In: Mathematical models of continental seas. Dynamic processes in the Southern Bight. Liège, 187-257.

- 1975. Ecometabolism of a shallow marine lagoon at Ostend (Belgium). In: Proceedings of the 10th European Symposium on Marine Biology. Ed. by G. Persoone \& E. Jaspers. University Press, Wetteren, 2, 485-562.

Pomeroy, L. R. \& Johannes, R. E., 1968. Occurrence and respiration of ultraplankton in the upper 500 meters of the ocean. Deep Sea Res. 15, 381-391.

Romanenko, V. I., 1964. Heterotrophic $\mathrm{CO}_{2}$ assimilation by bacterial flora of waters. Microbiology 33, 679-683.

Seki, H., Yamaguchi, Y. \& Ichimura, S., 1975. Turnover rate of dissolved organic materials in a coastal region of Japan at summer stagnation period of 1974. Arch. Hydrobiol. 75, $297-305$.

Sieburth, J. McN., 1977. International Helgoland Symposium: Convener's report on Informal Session on marine ecosystem research and man's dependence on the sea. Helgoländer wiss. Meeresunters. 30, 697-704.

Sorokin, Y. I., 1973. Data on biological productivity of the western tropical Pacific Ocean. Mar. Biol. 20, 177-196.

Wollast, R., 1976. Propriétés physico-chimiques des sédiments et des suspensions de la Mer du Nord. In: Modèle mathématique de la Mer du Nord. Rapport final. 4: Sedimentologie. Ed. par. J. C. J. Nihoul \& F. Gullentops. Liège, 139-160.

Author's address: C. Joiris

Laboratorium voor Ekologie en Systematiek

Pleinlaan 2

B-1050 Brussel

Belgium 